\title{
A simple method to evaluate the number of bradyrhizobia on soybean seeds and its implication on inoculant quality control
}

\author{
Claudio Penna ${ }^{1}$, Rosana Massa ${ }^{1}$, Florencia Olivieri ${ }^{1}$, Gabriel Gutkind ${ }^{2}$ and Fabricio Cassán ${ }^{3 *}$
}

\section{Correction}

The authors regret that an error appears in Penna etal. (2011). The fourth sentence in the section Formulation and evaluation of the selective medium "This compound was initially solubilized in $98 \%$ ethanol, sterilized using $0.2 \mu \mathrm{m}$ filters, added to $45^{\circ} \mathrm{C}$ YEM medium, and homogenized to obtain a final concentration of 0,2 g.l-1 of PCNB into the P-YEM medium". Must be replaced by the following "A solution of $10 \%$ PCNB in acetone, was diluted $1 / 5$ in Tween $800,5 \% \mathrm{v} / \mathrm{v}$ in water, sterilized using $0.2 \mu \mathrm{m}$ filters, added to $45^{\circ} \mathrm{C}$ YEM medium, and homogenized to obtain a final concentration of $0,04 \mathrm{~g} \cdot \mathrm{l}^{-1}$ of PCNB into the P-YEM medium".

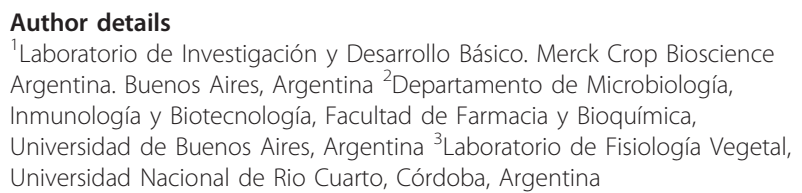

\section{Reference}

Penna C, Massa R, Olivieri F, Gutkind G, Cassán F (2011) A simple method to evaluate the number of bradyrhizobia on soybean seeds and its implication on inoculant quality control. AMB Express 1:21. doi:10.1186/2191-0855-1-21.

\footnotetext{
* Correspondence: fcassan@exa.unrc.edu.ar

${ }^{3}$ Laboratorio de Fisiología Vegetal, Universidad Nacional de Rio Cuarto,

Córdoba, Argentina

Full list of author information is available at the end of the article
}

Submit your manuscript to a SpringerOpen ${ }^{\circ}$ journal and benefit from:

- Convenient online submission

- Rigorous peer review

- Immediate publication on acceptance

- Open access: articles freely available online

- High visibility within the field

- Retaining the copyright to your article

Submit your next manuscript at $\boldsymbol{~ s p r i n g e r o p e n . c o m ~}$ 